\title{
Vagal Impairment of Gastric Secretion in Diabetic Autonomic Neuropathy
}

\author{
D. J. HOSKING, FREDA MOODY, I. M. STEWART, MICHAEL ATKINSON
}

British Medical fournal, 1975, 2, 588-590

\section{Summary}

Gastric acid output in response to insulin-induced hypoglycaemia and pentagastrin was measured in 18 diabetic patients with symptoms of autonomic neuropathy. Two patients had achlorhydria but the rest responded normally to pentagastrin. The acid output evoked by insulin-induced hypoglycaemia was low in 10 of the 16 patients who secreted acid in response to pentagastrin. These changes suggest that vagal impairment is common in diabetics with autonomic symptoms, which might explain the infrequency of duodenal ulcer in diabetics.

\section{Introduction}

The incidence of duodenal ulcer in diabetic patients is about a third of that in the non-diabetic population. ${ }^{12}$ This reduced incidence is usually ascribed to a decrease in gastric secretion, ${ }^{34}$ which in turn has been variously attributed to gastric mucosal atrophy, ${ }^{5}$ reflected in the increased incidence of pernicious anaemia in diabetics, ${ }^{6}$ and diabetic autonomic neuropathy.

Autonomic neuropathy in diabetes is thought to cause anorexia, vomiting, ${ }^{7}$ constipation, and diarrhoea, ${ }^{8} \cdot$ and the similarity between these symptoms and those occurring after surgical vagotomy) ${ }^{1}$ supports this view. Furthermore, these alimentary symptoms are often accompanied by impotence, bladder dysfunction, or postural hypotension, which are also thought to result from autonomic disturbance.

We assessed gastric acid secretion in 18 diabetics with various symptoms attributed to autonomic neuropathy using maximal stimulation with pentagastrin as a measure of parietal cell mass and the secretory response to hypoglycaemia as a measure of vagal function.

\section{Patients and Methods}

After informed consent had been obtained studies of gastric acid secretion were performed on 18 diabetic outpatients. Diabetic control had been satisfactory in all patients for several months before investigation. The patients were divided into three general clinical groups on the basis of their presenting autonomic symptoms: patients in cases 1-8 suffered from diarrhoea, those in cases 9-11 from recurrent episodes of vomiting, and in cases 12-18 from impotence or bladder dysfunction. There was some overlap of symptoms: patients in cases 1-4 also suffered from vomiting, and all 10 men were impotent; only in cases 12 and 15 were there bladder symptoms. The symptoms were classified as diabetic because they showed many of the described features of autonomic neuropathy and because other aetiological factors had been excluded by investigation (table I)

Laboratory procedure followed closely that described by Baron. ${ }^{11}$ Studies were performed in the morning after a 12-hour fast and

General Hospital, Nottingham NG1 6HA

D. J. HOSKING, M.D., M.R.C.P., Senior Registra

FREDA MOODY, S.R.N., Nurse Technicia

I. M. STEWART, M.B., M.R.C.P., Medical Registrar

MICHAEL ATKINSON, M.D., F.R.C.P., Consultant Physician abstinence from smoking. With the patient in a semi-recumbent position a nasogastric tube was passed into the stomach and its position checked after five minutes by the injection and reaspiration of $20 \mathrm{ml}$ of water. Patients were instructed not to swallow saliva and continuous aspiration of gastric secretions was performed by constant hand suction. Patency of the tube was maintained by the intermittent injection of air. Gastric juice was pooled for 15-minute periods, filtered, and its volume and $\mathrm{pH}$ recorded. Titratable acidity was measured by titration with $0 \cdot 1 \mathrm{M} \mathrm{NaOH}$ to $\mathrm{pH} 7 \cdot 0$, and gastric acid secretion was recorded as a concentration $(\mathrm{mmol} / \mathrm{l})$ or converted and expressed conventionally as $\mathrm{mmol} / \mathrm{h}$.

\begin{tabular}{|c|c|c|c|c|c|c|}
\hline $\begin{array}{l}\text { Case } \\
\text { No. }\end{array}$ & $\begin{array}{l}\text { Age } \\
\text { and } \\
\text { Sex }\end{array}$ & \begin{tabular}{|c|}
$\begin{array}{c}\text { Duration } \\
\text { of Diabetes } \\
\text { (Years) }\end{array}$ \\
\end{tabular} & Treatment & Retinopathy & $\begin{array}{c}\text { Peripheral } \\
\text { Neuropathy* }\end{array}$ & Nephropathy \\
\hline $\begin{array}{r}1 \\
2 \\
3 \\
4 \\
5 \\
6 \\
7 \\
8 \\
9 \\
10 \\
11 \\
12 \\
13 \\
14 \\
15 \\
16 \\
17 \\
18\end{array}$ & $\begin{array}{l}24 \mathrm{M} . \\
38 \mathrm{M} . \\
37 \mathrm{~F} . \\
59 \mathrm{M} . \\
54 \mathrm{~F} . \\
66 \mathrm{~F} . \\
58 \mathrm{M} . \\
21 \mathrm{~F} . \\
53 \mathrm{~F} . \\
56 \mathrm{~F} . \\
73 \mathrm{~F} . \\
44 \mathrm{M} . \\
50 \mathrm{M} . \\
37 \mathrm{M} . \\
51 \mathrm{~F} . \\
23 \mathrm{M} . \\
46 \mathrm{M} . \\
45 \mathrm{M} .\end{array}$ & $\begin{array}{r}7 \\
15 \\
15 \\
26 \\
45 \\
5 \\
7 \\
14 \\
20 \\
12 \\
9 \\
1 \\
9 \\
1 \\
1 \\
11 \\
16 \\
10\end{array}$ & $\begin{array}{l}\text { Insulin } \\
\text { Insulin } \\
\text { Insulin } \\
\text { Insulin } \\
\text { Insulin } \\
\text { CLP } \\
\text { CLP } \\
\text { Insulin } \\
\text { Insulin } \\
\text { Insulin } \\
\text { CLP } \\
\text { Insulin } \\
\text { Insulin } \\
\text { CLP } \\
\text { Insulin } \\
\text { Insulin } \\
\text { Insulin } \\
\text { Insulin }\end{array}$ & $\begin{array}{l}\text { H., E. } \\
\text { H.V. } \\
\text { N.V. } \\
\overline{-} \\
\overline{\text { B.C. }} \\
\text { H., E. } \\
\overline{\mathrm{H} .} \\
\overline{\text { B.C. }} \\
\overline{-} \\
\text { H., E. } \\
\overline{\text { B.C. }}\end{array}$ & $\begin{array}{c}++ \\
++ \\
+ \\
+ \\
+ \\
++ \\
+ \\
\text { E. M. G. } \\
++ \\
+ \\
+ \\
+ \\
+ \\
+ \\
+ \\
+ \\
+\end{array}$ & $\begin{array}{l}- \\
++ \\
+ \\
= \\
= \\
= \\
= \\
+ \\
+ \\
\pm \\
= \\
\pm \\
=\end{array}$ \\
\hline
\end{tabular}

* E.M.G. = Neurophysiological changes only. $+=$ loss of ankle jerks with or without E.M.G. = Neurophysiological changes only. $+=$ loss of ankle jerks with or without vibration sense in feet.

$t+=$ Albuminuria. $++=$ Albuminuria and raised blood urea $(>40 \mathrm{mg} / 100 \mathrm{ml})$ $\dagger+=$ Albuminuria. $++=$ Albuminuria and raised blood urea $(>40 \mathrm{mg} / 100 \mathrm{ml})$
CLP $=$ Chlorpropamide. $\mathrm{H}$. = Haemorrhages. E. $=$ Exudates. $\mathrm{N} . \mathrm{V} .=$ Neovascularizaion, B.C. = Background changes.

Insulin Dose and Blood Sugar Measurements.-Neutral insulin (Insulin Novo Actrapid) was given intravenously only after 60 minutes' basal collection of gastric secretion had been completed, and additional intravenous insulin was given 3-120 minutes after the first dose in 11 patients to lower the blood sugar level to below $2.22 \mathrm{mmol} / 1(40 \mathrm{mg} / 100 \mathrm{ml})$. Clinical signs of hypoglycaemia were seen in all patients. An indwelling venous cannula was inserted to facilitate frequent sampling for venous blood sugar concentration and provide a route for $50 \%$ dextrose solutions should they be required. Blood sugar was measured by the glucose oxidase method, but in addition rapid estimations were provided by a reflectance meter technique (Dextrostix, Ames). Blood sugar was measured after completion of the basal collection and thereafter every 15 minutes until the end of the study (at which time normoglycaemia was restored, if not already present, by intravenous or oral administration of dextrose solutions).

Pentagastrin Test.-Immediately after completion of the insulin test pentagastrin $6 \mu \mathrm{g} / \mathrm{kg}$ body weight was injected subcutaneously and gastric secretion aspirated for a further 60 minutes.

\section{Results}

A minimum blood sugar of $<1.94 \mathrm{mmol} / 1(35 \mathrm{mg} / 100 \mathrm{ml})$ was obtained in all but two patients (who experienced severe neuroglycopenic symptoms at a blood sugar of $2.50 \mathrm{mmol} / 1(45 \mathrm{mg} / 100 \mathrm{ml})$. The length of the post-hypoglycaemia collection tended to relate inversely to the time taken to obtain adequate hypoglycaemia, and in all but one case 15-minute collections were continued for at least 75 minutes (table II).

After the insulin injections there was a mean linear fall $( \pm$ S.E. of 
TABLE II-Gastric Acid Secretion After Insulin and Pentagastrin

\begin{tabular}{|c|c|c|c|c|c|c|c|c|}
\hline Case No. & $\begin{array}{c}\text { Minimum } \\
\text { Blood Sugar } \\
(\mathrm{mmol} / \mathrm{l})\end{array}$ & $\begin{array}{c}\text { Duration of } \\
\text { Post-hypoglycaemic } \\
\text { Collection } \\
\text { (min) }\end{array}$ & $\begin{array}{c}\text { Basal } \\
\text { Acid } \\
(\mathbf{m m o l} / \mathbf{l})\end{array}$ & $\begin{array}{c}\text { Maximum } \\
\text { Acid After } \\
\text { Insulin (mEq/1) } \\
(\mathbf{m m o l} / \mathbf{l})\end{array}$ & $\begin{array}{c}\text { Maximum } \\
\text { Difference in } \\
\text { Acid after Insulin } \\
(\mathrm{mmol} / \mathrm{l})\end{array}$ & $\begin{array}{l}\text { P.A.O.I } \\
(\mathrm{mmol} / \mathrm{h})\end{array}$ & $\begin{array}{l}\text { P.A.O.Pg } \\
(\mathrm{mmol} / \mathrm{h})\end{array}$ & $\begin{array}{c}\text { P.A.O.I/P.A.O.Pg } \\
(\%)\end{array}$ \\
\hline $\begin{array}{r}1 \\
2 \\
3 \\
4 \\
5 \\
6 \\
7 \\
8 \\
9 \\
10 \\
11 \\
12 \\
13 \\
14 \\
15 \\
16 \\
17 \\
18\end{array}$ & $\begin{array}{l}1.78 \\
1.28 \\
0.94 \\
1.11 \\
0.78 \\
2.50 \\
1.67 \\
1.44 \\
0.67 \\
1.78 \\
1.67 \\
1.22 \\
1.33 \\
1.00 \\
1.50 \\
1.28 \\
2.50 \\
1.67\end{array}$ & $\begin{array}{r}60 \\
75 \\
90 \\
90 \\
90 \\
75 \\
120 \\
90 \\
75 \\
90 \\
120 \\
90 \\
75 \\
120 \\
120 \\
105 \\
75 \\
105\end{array}$ & $\begin{array}{r}61 \cdot 5 \\
74.5 \\
59 \cdot 5 \\
0 \\
45 \cdot 7 \\
8 \cdot 2 \\
0 \\
38 \cdot 1 \\
83 \cdot 5 \\
41 \cdot 4 \\
48 \cdot 3 \\
0 \\
20 \cdot 8 \\
50.0 \\
97.0 \\
55.0 \\
68 \cdot 2 \\
61.4\end{array}$ & $\begin{array}{r}60.5 \\
59.0 \\
52.0 \\
0 \\
58.6 \\
24.0 \\
32.8 \\
128.2 \\
91.5 \\
69.0 \\
99.4 \\
3.5 \\
106.9 \\
101.5 \\
119.0 \\
32.0 \\
60.6 \\
45.7\end{array}$ & $\begin{array}{c}-1 * \\
-15.5^{*} \\
-7.5^{*} \\
0 \\
-12.9^{*} \\
15 \cdot 8^{*} \\
32.8 \\
90 \cdot 1 \\
8 \cdot 0^{*} \\
27.6 \\
51 \cdot 1 \\
3.5 \\
86.1 \\
51.5 \\
22 \cdot 0 \\
-23.0^{*} \\
-7.6^{*} \\
-15.7^{*}\end{array}$ & $\begin{array}{r}2.42 \\
1.04 \\
3 \cdot 12 \\
0 \\
1.28 \\
1.46 \\
1.62 \\
28.5 \\
4.34 \\
5.10 \\
12.82 \\
0 \\
20 \cdot 04 \\
13.64 \\
14.22 \\
1.44 \\
4.84 \\
2.54\end{array}$ & $\begin{array}{c}29 \cdot 84 \\
21 \cdot 86 \\
22 \cdot 12 \\
0 \\
28 \cdot 72 \\
14 \cdot 32 \\
2 \cdot 76 \\
29 \cdot 24 \\
20 \cdot 34 \\
20 \cdot 46 \\
26 \cdot 10 \\
0 \\
37 \cdot 58 \\
23 \cdot 42 \\
20 \cdot 66 \\
22 \cdot 28 \\
54 \cdot 06 \\
33 \cdot 30\end{array}$ & $\begin{array}{r}8 \cdot 11 \\
4 \cdot 76 \\
14 \cdot 10 \\
4 \cdot 46 \\
12 \cdot 40 \\
58 \cdot 70 \\
97 \cdot 47 \\
21 \cdot 34 \\
24 \cdot 93 \\
49 \cdot 12 \\
53 \cdot 33 \\
58 \cdot 24 \\
68 \cdot 83 \\
6 \cdot 46 \\
8 \cdot 95 \\
7 \cdot 63\end{array}$ \\
\hline
\end{tabular}

* Abnormal values according to Hollander's criteria, ${ }^{12}$ indicating impaired vagal function.
Conversion: SI to Traditional Units-Glucose: $1 \mathrm{mmol} / 1 \approx 18 \mathrm{mg} / 100 \mathrm{ml}$.

mean) in blood sugar of $0.12 \pm 0.011 \mathrm{mmol} \mathrm{1}^{-1} \mathrm{~min}^{-1}(2 \cdot 17 \pm 0.19 \mathrm{mg} /$ $100 \mathrm{ml} / \mathrm{min}$ ). In the earlier tests an initial insulin dose of $0.4 \mathrm{U} / \mathrm{kg}$ body weight was given but this invariably required supplementation before adequate hypoglycaemia was achieved. In later tests a dose of soluble insulin equal to the patients' usual total daily insulin requirement was found to be more effective in producing the desired level of hypoglycaemia.

Hollander ${ }^{12}$ considered vagal function to be intact if there was an increase of more than $20 \mathrm{mmol} / \mathrm{l}$ in titratable acidity in two consecutive 15-minute periods after insulin-induced hypoglycaemia (blood sugar $<2.22 \mathrm{mmol} / 1(40 \mathrm{mg} / 100 \mathrm{ml})$ compared with the basal concentration. If the basal samples contained no free acid then vagal function was regarded as being intact if the post-insulin concentration exceeded $10 \mathrm{mmol} / \mathrm{l}$. These criteria for intact vagal function were not fulfilled in five patients with diarrhoea, one with vomiting, and three with impotence (table II). Two other patients (cases 4 and 12) had pentagastrin-fast achlorhydria and, therefore, vagal function was not susceptible to testing by insulin-induced hypoglycaemia. The rate of fall of blood sugar was $0.13 \pm 0.020 \mathrm{mmol}^{-1} \mathrm{~min}^{-1}(2.34 \pm 0.36 \mathrm{mg} /$ $100 \mathrm{ml} / \mathrm{min})$ and the absolute fall $11 \cdot 1 \pm 1 \cdot 11 \mathrm{mmol} / 1(199 \pm 20 \mathrm{mg} /$ $100 \mathrm{ml}$ ) in those negative on insulin testing (impaired vagal function) and $0.11 \pm 0.009 \mathrm{mmol} 1^{-1} \mathrm{~min}^{-1}(1.92 \pm 0.17 \mathrm{mg} / 100 \mathrm{ml} / \mathrm{min})$ and $7 \cdot 88 \pm 1.44 \mathrm{mmol} / 1(142 \pm 26 \mathrm{mg} / 100 \mathrm{ml})$ respectively in those positive on insulin testing (intact vagal function); these differences were not significant. In those with negative responses the basal hydrogen ion concentration was higher, $57 \cdot 5 \pm 7 \cdot 1 \mathrm{mmol} / \mathrm{l}$, than those with positive responses, $42 \cdot 2 \pm 11 \cdot 2 \mathrm{mmol} / \mathrm{l}$, but this d:fference was not significant. The maximum hydrogen ion concentration after hypoglycaemia in the group with impaired vagal function was lower, $53.8 \pm 6.5 \mathrm{mmol} / \mathrm{l}$, than that in those with intact function, $93.8 \pm 12.4 \mathrm{mmol} / 1(\mathrm{P}<0.01)$.

Peak acid output (P.A.O.) after pentagastrin was normal in all but three patients, two of whom had achlorhydria (table II). Mean P.A.O. was slightly higher in the group with negative insulin test results $(27.4 \mathrm{mmol} / \mathrm{l})$ than in those with iptact vagal function (22.8 $\mathrm{mmol} / \mathrm{h}$ ). This difference was not significant and both figures were close to the reported mean normal value of $25.25 \mathrm{mmol} / \mathrm{h}^{13}$

P.A.O. after insulin expressed as a percentage of the P.A.O. after pentagastrin (P.A.O.I/P.A.O.Pg \%) reflects the proportion of the parietal cell mass capable of being maximally stimulated by the vagus and can thus be used as a quantitative index of vagal intactness. The range for intact vagal function is $45-165 \% \cdot{ }^{14}$ Ten patients had values of less than $40 \%$-that is, values similar to those found after surgical vagotomy-achlorhydria was found in two patients, and of the remaining six only one was clearly normal, five falling in the lower part of the normal range with values of $49-68 \%$ (table II). The mean values for diabetic patients with diarrhoea did not differ significantly from those with impotence or bladder dysfunction.

\section{Discussion}

Though we performed no gastric mucosal biopsies the normality of the gastric secretory response to pentagastrin makes it unlikely that gastric mucosal atrophy is common in diabetes. The serum $B_{12}$ level was normal in all patients, and only two of the 18 patients had achlorhydria after pentagastrin. These findings agree with those of others ${ }^{815}$ who used histamine as the secretory stimulus, and it seems unlikely that the parietal cell mass is reduced in most diabetics.

The use of insulin in assessing whether gastric vagal innervation is intact presents problems in the diabetic patient; more insulin is required to induce hypoglycaemia than in non-diabetic patients. Sinee all our patients who needed insulin were being treated with beef insulins we used a pork insulin in tests of vagal function in the hope that its lower antigenicity ${ }^{16}$ would reduce variations in insulin requirements and help to standardize the dose in relation to body weight. This did not happen, but we found that an initial dose of soluble insulin equal to the total daily requirement usually produced adequate hypoglycaemia. Those patients on oral hypoglycaemic agents were given an initial insulin dose of $0.4 \mathrm{U} / \mathrm{kg}$, which often, however, required augmentation.

The rate of fall of the blood sugar level was similar in all patients and hence the time required to induce hypoglycaemia was longer in those patients with high initial blood sugar levels. Unfortunately the problem of high initial blood sugar levels cannot be overcome by performing the test on an inpatient basis giving the regular dose of insulin on waking. ${ }^{7}$ The longer time required to induce hypoglycaemia in diabetics compared with normal people may lead to premature discontinuation of the test before the secretory response has occurred. This did not occur in our patients, however, because the collection was usually continued for at least $\mathbf{7 5}$ minutes after hypoglycaemia, and during such a period the secretory response is demonstrable in $95 \%$ of unoperated duodenal ulcer patients. ${ }^{18}$

Our findings indicate that many diabetics with symptoms usually attributed to autonomic neuropathy show evidence of impaired vagal function. On Hollander's ${ }^{12}$ criteria nine out of 16 diabetics who were suitable for testing showed such impairment. By the more preferable P.A.O.I: P.A.O.pg 10 of the 16 were clearly abnormal and in five others the ratio lay low in the normal range. This incidence is higher than that reported by Dotevall et al., ${ }^{17}$ who found abnormality in only two out of 11 diabetics-most of whom had peripheral neuropathy and retinopathy though little data were given about gastrointestinal and genitourinary symptoms. Langer ${ }^{1}$ found that the P.A.O.I: P.A.O. $\mathrm{Pg}_{\mathrm{g}}$ was less than $40 \%$ in three out of 10 diabetics without recorded autonomic symptoms. The fact that we selected for study only those diabetics who showed autonomic symptoms might account for our finding a higher incidence of gastric vagal impairment.

The role of impaired vagal function in the genesis of alimentary symptoms in diabetes is uncertain. We did not study diabetics without autonomic symptoms as controls, but certainly abnormality in insulin-induced gastric secretion was no commoner in those with diarrhoea or vomiting than in those with genitourinary symptoms. Oesophageal motility studies in diabetics provide further evidence of vagal impairment, 20 and 
since in the individual patient the degree of abnormality of oesophageal motility does not correlate closely with that of insulin-induced gastric secretion vagal impairment may predominantly affect different parts of the gut in different patients and may indeed be as highly selective as current surgical vagotomy. Vagal impairment complicating diabetics may, by the resulting reduction in gastric acid secretion, account for the low incidence of duodenal ulcer in this disease, and our findings indicate that this is a more likely mechanism than reduction of parietal cell mass as a consequence of gastric mucosal atrophy.

We thank the patients for their co-operation and Dr. M. V. Wells and Dr. S. P. Allison for referring them for study. We also thank the medical illustration department of Nottingham General Hospital.

Requests for reprints should be addressed to M.A.
2 Zschoch, H., Deutsche Zeitschrift fur Verdauungs-und Stoffwechselkrankheiten, 1965, 25, 97.

3 Dotevall, G., Acta Medica Scandinavica, 1961, 170, 59.
4 Segovia, D. A., Torre, E., and Domenge, L., Revista de Investigacion Clinica, 1960, 12 , 45.

5 Angervall, L., Dotevall, G., and Lehmann, K. E., Acta Medica Scandinavica, 1961, 169, 339

6 Wilkinson, J. F., British Medical fournal, 1963, 1, 676.

7 Kassander, P., Annals of Internal Medicine, 1958, 48, 797.

Whalen, G. E., Soergel, K. H., and Geenen, J. E., Gastroenterology, $1969,56,1021$.

9 Malins, J. M., and Mayne, N., Diabetes, 1969, 18, 858.

10 Barnes, A. D., and Cox, A. G., in After Vagotomy, ed. J. A. Williams and A. G. Cox, p. 221. London, Butterworth, 1969.

11 Baron, J. H., Scandinavian Fournal of Gastroenterology, 1970., Suppl. 6, 9. 12 Hollander, F., Gastroenterology, 1946, 7, 607.

13 Johnston, D., and Jepson, K, Lancet, 1967, 2,585

14 Venables, C. W., and Johnston, I. D., British fournal of Surgery, 1969, 57,757 .

15 Marks, I. N., Schuman, C. R., and Shay, H., Annals of Internal Medicine, $1959,51,227$.

16 de Mowbray, R. R., et al., Diabetologia, 1971, 7, 476

17 de Mowbray, R. R., et al., Diabetologia, 1971, 7, 476.

17 Dotevall, G., et al., Acta Medica Scandina

18 Burns, G. P., et al., Gut, 1969, 10, 820.

19 Langer, L., Acta Medica Scandinavica,

\title{
Localized Avascular Necrosis of Lesser Curve of Stomach Complicating Highly Selective Vagotomy
}

\author{
JAN F. HALVORSEN, PETER HEIMANN， JAN H. SOLHAUG， KNUT B. JACOBSEN
}

British Medical fournal, 1975, 2, 590-591

\section{Summary}

The fourth case of localized avascular necrosis of the lesser curve of the stomach after highly selective vagotomy is reported. The pathogenesis was probably related to the relative poverty of the submucosal blood supply along the lesser curve. This complication may be prevented by peritonealizing the lesser curve before closing the abdominal wall.

\section{Introduction}

Interest in highly selective vagotomy without a drainage procedure (H.S.V.) in the treatment of duodenal ulcer is increasing. The operation effectively reduces the acid output and early and late complications are less frequent than after other operations for duodenal ulcer. ${ }^{1-12}$ Among 350 patients who were followed for up to five years after H.S.V. in Leeds and Copenhagen there were no cases of proved recurrent duodenal ulceration and only two cases of gastric ulcer. ${ }^{11}$

Only three deaths after H.S.V. have been reported, two of them after operation for duodenal ulcer $^{13} 14$ and one after operation for gastric ulcer.11 We report here the third death after H.S.V. for duodenal ulcer, which bears a striking resemblance to those reported by Newcombe ${ }^{13}$ and Hall et al..$^{14}$

\footnotetext{
Department of Surgery, Haukeland Sykehus, University of Bergen, Bergen, Norway

J. F. HALVORSEN, M.D., Senior Registrar

P. HEIMANN, M.D., PH.D., Professor of Surgery

J. H. SOLHAUG, M.D., Senior Registrar

Department of Pathology, Gade Institute, Haukeland Sykehus,

University of Bergen, Bergen, Norway

K. B. JACOBSEN, M.D., Consultant Pathologist
}

\section{Case Report}

This 36-year-old man had a three-year history of recurrent duodenal ulceration. On 12 February 1974 H.S.V. was performed. The duodenal cap was scarred but there was no stenosis. No difficulty was encountered during the operation. Diathermy was not used, all vessels and nerves being ligated with 00 -silk. The raw surface of the lesser curve was not peritonealized. The patient was participating in a postoperative metabolic study, for which a subclavian catheter for intravenous alimentation and a nasogastric tube had been positioned.

Two days after operation the patient had pains in the epigastrium and left hypochondrium and became dyspnoeic. Chest $x$-ray examination showed a large bilateral hydrothorax. Thoracocentesis yielded $1400 \mathrm{ml}$ of milky fluid from the right pleura and $400 \mathrm{ml}$ from the left pleura. The fluid was a diluted solution of Intralipid, which the patient had received through the left subclavian vein. The subclavian catheter was removed.

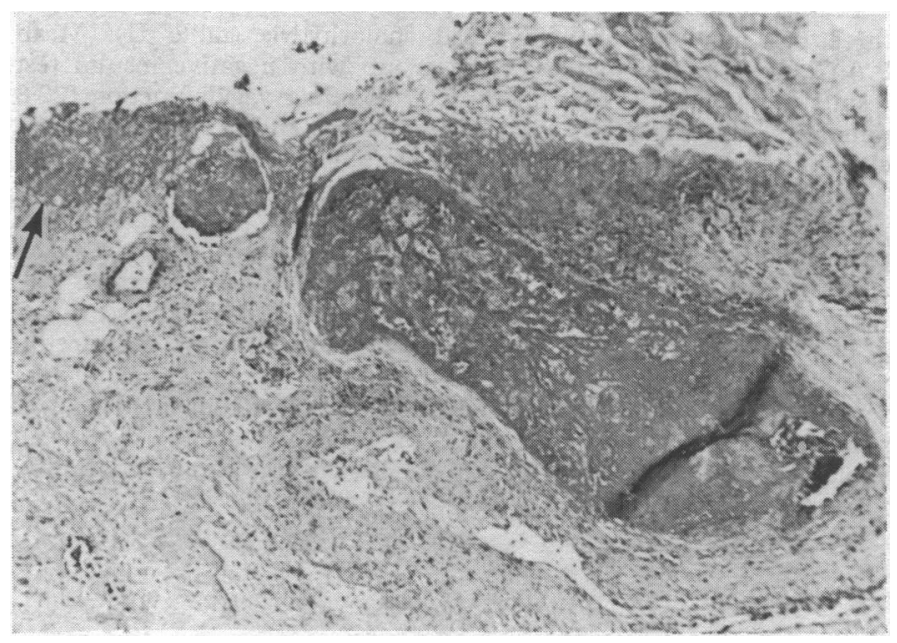

FIG. 1-Microscopic appearance of gastric perforation showing necrotic border (arrowed) and thrombosed vessel. $(H$. and $E$. $\times 36$.)

For the next three days the patient remained comparatively well. He passed flatus on the third day after operation, but the abdomen 